\title{
A Collection of Review on Concept of Leaders, Leadership and Importance of Leaders
}

\author{
P. Shrivastava ${ }^{1 *}$, K. K. Shrivastava ${ }^{2}$ and Anupama Verma ${ }^{3}$ \\ ${ }^{1}$ Ag. Extn., JNKVV, Jabalpur, India \\ ${ }^{2}$ Department of Agricultural Extension, IGKV, Raipur, India \\ ${ }^{3}$ Institute of Agri Business Management, JNKVV, Jabalpur, India \\ *Corresponding author
}

\begin{abstract}
A B S T R A C T
A basic function of extension is to assist the transfer of agricultural technology by ensuring that an adequate amount of high quality knowledge about it is present in the farming community for sustained agricultural development. Studies of the personal characteristics of power holders indicate that they possess high social status and are well known and respected in their communities. While leaders may share some relevant characteristics in similar situations, they also very likely differ in others so that their total personalities are not alike. Informal leadership is earned and maintained by the individuals' technical competence, social accessibility and conformity to the systems norms. Through their conformity to the systems norms, opinion leaders serve as a model for the innovation behaviour of their followers. A leader's action and a leader's professed beliefs must be congruent or at least compatible. Effective leadership - and again this is very old wisdom is not based on being clever; it is based primarily on being consistent. Anybody who comes forward with a good solution may be immediately selected as a leader to guide the future action of the group. People with passive and submissive tendency usually follow the leader. Leaders know well that innovation and change all involve experimentation, risk and failure. They proceed anyway. One way of dealing with the potential risk and failures of experimentation is to approach change through incremental steps and small wins.
\end{abstract}

\section{Introduction}

A basic function of extension is to assist the transfer of agricultural technology by ensuring that an adequate amount of high quality knowledge about it is present in the farming community for sustained agricultural development. As defined by Roling (1988) extension is purposeful communication intervention deployed by an institution to induce change in voluntary behaviours with a presumed public or collective utility. Choice of leadership in rural areas tends to be more on the basis of known personal qualities of the individual then in urban areas, mainly because of far greater face-to-face contacts and more intimate knowledge of individuals than is possible in urban areas. Research in 
community power structure studies conducted by sociologists in recent years indicate that individuals who hold influence and power do exist in most communities, and operate as a primary friendship clique, and that power is concentrated in the hands of a few persons. Studies of the personal characteristics of power holders indicate that they possess high social status and are well known and respected in their communities. The concept of leadership has undergone considerable change as research in this area of study progressed. Leadership was considered at one time to be a set of traits handed down chiefly through heredity from one person to another. Recent studies have indicated that differences between leaders and other members of a group are not as sharply defined as were previously believed, and have produced little evidence of universal character traits that would describe essential and distinguishing leadership qualities. Further, while leaders may share some relevant characteristics in similar situations, they also very likely differ in others so that their total personalities are not alike. In addition traits which are relevant to leadership roles are not rare but may be distributed widely in a population, making many individuals eligible for leadership positions. In other words leadership abilities need not therefore be exclusively the possession of a small narrowly defined class or type of individual, nor is it necessary for leaders as a group to be alike or sharply different from "followers". With proper training, several persons can perform a wide variety of leadership functions. Opinion leadership is the degree to which an individual is able to influence other individuals' attitudes or overt behaviour informally in a desired way with relative frequency. This informal leadership is earned and maintained by the individuals' technical competence, social accessibility and conformity to the systems norms. Through their conformity to the systems norms, opinion leaders serve as a model for the innovation behaviour of their followers Opinion leaders thus exemplify and express the systems structure. There is all likelihood that many of the elected panchayat leaders can successfully play the role of opinion leadership and serve as a vital link in the extension system for dissemination of latest agricultural innovations to the farming community.

With the above points of reference in view a research was conducted with the following specific objective:

To collect the review of literature on concept of leaders, leadership and importance of leaders.

\section{Materials and Methods}

Secondary data in the form of published literature like journals, magazines, thesis, books, etc. were scanned to collect and review the available literature on leadership which is systematically presented.

\section{Results and Discussion}

The reviewed literature is presented under the following sub heads:

\section{Concept of leaders and leadership}

Bogardus (1934) stated that - "Leader is a person who exerts special influence over a number of people". He further emphasized that there must be both special influence and a number of people involved.

Bogardus (1934) also stated that leadership is personality in action under group conditions. It is interaction between specific traits of one person and other traits of the many, in such a way that the course of action of the many is changed by the one. 
Sanderson (1940) opined that leader is a mechanism for group action. He stated that leadership is a means of directing the action of group in desirable activities.

Haiman (1951) defined leadership as a process of directing, guiding, influencing and controlling of thoughts, feelings or behaviour of other human beings.

Tennebaum et al., (1961) defined leadership in terms of interpersonal influence that is exercised in specific situations and directed through communication process and is definitely goal oriented.

Beal et al., (1962) stated that - "An individual is a leader in any social situation in which his ideas and actions influence the thoughts and behaviour of others".

On leadership they stated, the very act of leadership in whatever form observed, develops initiative, creativity and mature responsibility. They also stated that leadership was a learned behaviour and any one could improve himself in it by proper study and application, It is also situational.

Leagans (1963) recorded that a leader was one who had ability and willingness to recognize the common good and enthusiasm to promote it without expectation of material reward out of it.

Kuppuswamy (1973) stated that an effective leader was one who saw that the members of the group enjoyed their membership and also exerted themselves to complete the task undertaken.

Singh (1973) opined that an individual might be considered a leader by virtue of the fact that local residents recognised and acknowledged him to be one.
Stogdill (1974) says that from whatever angle the leadership is viewed, one thing is common that leadership is the act of exercising special influence on the members of the group, who are technically called as followers, towards the achievement of the group goal. This concept is applicable to any type of leadership in any country and at any time.

Singh (1987) was of the view that the leadership is the ability to persuade others to seek defined objectives enthusiastically. It is the human factor that binds a group together and motivates it towards goal. The leadership is so important to group accomplishment that the people have been concerned about it since the beginning of recorded history. The importance of leadership is even much more in the case of group actions and group decisions.

Dasgupta (1989) stated that "Opinion leaders" are people who are sought by their fellow members of the community for information and advice on agricultural innovations. They do not only disseminate information but also influence the action on the content of the information by their fellow community members. Although they have been designated "as opinion leaders" by most studies, they have also been designated as "lay leaders", "informal leaders", "agricultural leaders", "communicators" or just simply as leaders.

Robbins (1997) reported that leaders work from high - risk positions - indeed, they are often temperamentally disposed to seek out risk and danger, especially when opportunity and reward appear high. Leaders, who are concerned with ideas, relate to people in more intuitive and empathetic ways. Leaders establish direction by developing a vision of the future; then they align people by communicating this vision and inspiring them to overcome hurdles. 
Chaubey et al., (1999) stated that there are always some leaders and others followers in every group and organisation. The ability to get missions accomplished through leadership abilities is a factor that is stressed in all types of human endeavours. Unfortunately, the term leadership is most misunderstood term in organisation to-day. Very often it tends to be equated with enthusiasm and energy and a generally pleasing personality. Although these virtues are very desirable in any kind of leader, leadership can not be reduced to a simple little formula.

Maxwell (1999) has written in his book - "To build trust, a leader must exemplify competence, connection and character". "How do leaders earn respect? By making sound decisions, admitting their mistakes, and putting what's best for their followers and the organisation ahead of their personal agendas".

"When people respect someone as a person, they admire her. When they respect her as a friend, they love her. When they respect her as a leader they follow her."

"Leaders who want to succeed maximise every asset and resource they have for the benefit of their organisation".

Dahama and Bhatnagar (2001) have quoted a few definitions in their book-

"The leader is the servant of the group. The position of the leaders is an essential mechanism of affective group organisation".

"Leaders are persons who are selected by the people because of their special interest or fitness to work on some phase of the local programmes".

"A leader is one who helps the members of the group, as an individual, he accepts the responsibility for thinking through problems and working out solutions that need to be discovered."
"An individual is a leader in any social situation in which his ideas and actions influence the thoughts and behaviour of others".

"Leader is a person who has been spontaneously considered, or chosen, as being influential in a specific situation or situations".

Maxwell (2001) says - "What is leadership? Remove for a moment the moral issues behind it, and there is only one definition: Leadership is the ability to obtain followers." Once you define leadership as the ability to get followers, you work backward from that point of reference to figure out how to lead.

The final requirement of effective leadership is to earn trust. Otherwise there won't be any followers. A leader is someone who has followers. To trust a leader, it is not necessary to agree with him. Trust is the conviction that the leader means what he says. It is a belief in something very old-fashioned called "integrity". A leader's action and a leader's professed beliefs must be congruent or at least compatible. Effective leadership - and again this is very old wisdom - is not based on being clever; it is based primarily on being consistent.

In this world of rapid change and discontinuities, the leader must be out in front to encourage change and growth and to show the way to bring it about. He must first understand the two important requisites to bringing about change: knowing the technical requirements of the change and understanding the attitude and motivational demands for bringing it about".

Ray (2001) was of the opinion that leading is the process of influencing people so that they will strive willingly and enthusiastically towards attainment of the organisation and group goals. Leadership skill is a combination 
of four major ingredients: (a) the ability to use power effectively and in a responsible manner, (b) the ability to comprehend that human beings have differing motivation forces at different times and in different situations, (c) the ability to inspire, and (d) the ability to act in a manner that will develop a climate conducive to responding to and arousing motivations.

Blanchard and Muchnick (2004) recorded that - "Leadership effectively means more than just getting results. It means getting the commitment of the team. Many leaders focus only on the results part and forget about their people. They bang people over their heads until the job gets done. Their definition of success is the team's short-term output. The true test of leadership on the other hand, is to win the trust and respect of the team, keep their motivation running high and help them reach new heights. As a result the team will work together and consistantly perform well over time - even if the leader is not around."

Chakraborty and Chakraborty (2004) have quoted Jai B.P. Sinha as follows - "A nurturant leader cares for his subordinates, shows affection, takes personal interest in their well being and above all is committed to their goal. In order to be effective, however, he makes his nurturance contingent on the subordinate's task accomplishment. The leaders guides and directs them to work hard and to maintain a high level of productivity. Those who do meet his expectations are reinforced by nurturance. In the process there develops relationship of understanding, warmth and interdependence".

Adair (2005) says that - "Of course managers must have the technical competence to achieve results, but they must also have a different kind of competence: the understanding and skill necessary to get work done effectively by others. In short, they need to be able to lead. As some of the older methods of motivation become less effective the importance of the leader increases. Good fringe benefits and welfare provisions may attract people to an organisation but they will not have much effect on actual performance. More and more managers have to stand or fall by their performance as leaders".

According to Chitambar (2005) the term leader implied a person who was clearly distinguished from others in power, status, visibility and such traits of character as intelligence, integrity, courage, wisdom and judgement. The concept while recognising the importance of the environment, persisted in viewing leadership as a matter of specific traits and characteristics. Possession of these traits would thus (it was thought) somehow give the individual the role of leader in many if not most group situations.

Mohanty (2005) is of the view that the question of a leader arises only after the emergence of structuralisation of a group. There may be good deal of discussions and suggestions for attaining a common objective. Anybody who comes forward with a good solution may be immediately selected as a leader to guide the future action of the group. People with passive and submissive tendency usually follow the leader.

The leader is the centre around which all the wheels of a group or organisation move. In view of his distinct and special position within the group structure the leader greatly determines the group structure, group activities, ideologies, moral and goals of the group. One can not conceive of a group or an organisation without a leader and any group without a leader will disintegrate within no time as there will be no one to coordinate the functions of the group. Baldoni (2006) in his book has quoted Carlos Ghosh, CEO Renault - "Leadership that lasts is leadership that 
delivers because that's what feeds credibility. People are willing to go to the extra mile, they're willing to work much more, they are willing to sacrifice, but they want some kind of achievement.

Baldoni also said that leadership, like a finely crafted story, is an act of persuasion to a point of view that embraces doing good for individuals, teams, and the organisation. This is the ideal. The reality is that leadership is persuasion to a point of view that is good for the organisation but involves tough choices about teams and individuals. It is upto the leader to make the right call at the right time often the choices are difficult and painful.

Posner (2006) has written in his best-seller that - "Leaders are pioneers - people who are willing to step out into the unknown. They search for opportunities to innovate, grow and improve. But leaders aren't the only creators or originators of new products, services or processes. In fact, its more likely that they're not: innovation comes more from listening than from telling. Product and service innovations tend to come from customers, clients, vendors, people in the labs, and people on the front lines; process innovations, from the people doing the work. Sometimes a dramatic external event thrusts an organisation into a radically new condition.

Sharma (2006) is of the opinion that leadership is all about focused action in the direction of worthy purpose. Leadership is about realising that the impossible is generally the untried. Many people think that a leader is the man or the woman with the title of CEO or President. Actually leadership is not about position, it is about action. Leadership is not about managing things but about developing people. Quite simply leadership is about helping people to liberate the fullness of their talent while they pursue a vision you have helped them understand is a worthy and meaningful one. Verma (2006) stated that leaders must aim to inspire their workforce. To achieve this end they must appear authentic and filled with integrity. Integrity demands that they expose themselves to the same risks and give themselves the same privileges that are available to the workforce. Further they must show that they are willing to lead from the front and not content to sit in luxury while workers at the bottom sweat it out.

Leaders cannot have one standard for themselves and another for their subordinates. They need to show that they judge themselves by the same yardstick by which they judge others. When authentic leaders reprimand the workforce for failures then that reprimand is readily accepted and doesn't become a cause for resentment. On the other hand, when a leader with double standards chooses to make comments then those comments are liale to raise anger and beat morale.

Mathur (2007) narrates that leadership is such an affair in which two parties are involved. One is that which leads, make such suggestions which are acceptable to others, acts as model and gives command etc. and the other is that which is lead, excepts the suggestions of the first party, and follow the commands. The cooperation of these two parties is essential for the proper functioning of leadership. The leader should be acceptable to the followers. He must always see that his followers take his advice accept his opinions and perform those actions which he approves of.

Vatsyayan (2007) says that in every group there are several leaders. A leader is a person who by virtue of magnetism of his personality, social status or economic affluence is able to command respect from or dominate the wills of a group of persons so as to be able to mould and direct their energies 
into channels of his choice. A leader is a person who is both respected and obeyed by his followers. Unless trust and respect are both simultaneously present there can be no effective leadership.

Prasad (2007) analysed the definitions of leadership and brought out certain features which are as follows: -

Leadership is a continuous process of behaviour; it is not one shot activity.

Leadership may be seen in terms of relationship between a leader and his followers which arises out of their functioning for common goals.

By exercising his leadership, the leader tries to influence the behaviour of individuals or group of individuals around him to achieve common goals.

The followers were willingly and enthusiastically ready to achieve those goals.

Leadership gives an experience of help to followers to attain common goals.

Leadership is exercised in a particular situation at a given point of time and under specific set of circumstances.

Northouse (2007) writes in his book that through the years, leadership has been defined and conceptualised in many ways. The component common to nearly all the classifications is that leadership is an influence process that assists groups of individuals towards goal attainment. Leadership is defined as a process whereby an individual influences a group of individuals to achieve a common goal.

Because leaders and followers both are part of the leadership process, it is important to address issues that confront followers as well as those that confront leaders. Leaders and followers should be understood in relation to each other.

Vas and Vas (2007) inferred from the story of greedy jackal that - "Greed clouds judgement and is dangerous for your well being. Sadly, such mental aberrations very often negate what gracious fate offers by building us to its bounty. As a leader, you are more exposed to such temptations; to steer clear of it all you should never let your gaurd down.

\section{Importance of leaders}

Many researchers and authors had underlined the important role played by various leaders in developmental programme. A few noteworthy amongst them are as follows:-

Brunner and Young (1949) concluded that local leadership were indispensable for the development and implementation of development programmes.

Wilkening (1952) pointed out that three fold purpose was served by local leaders in the process of communication and diffusion of farm information.

Raheja (1956) stressed the importance of rural leadership in the intensive cultivation scheme and pointed out that leaders exercised a great influence on the members in their acceptance or resistance to new practice.

Mehta (1972) pointed out that leaders played an important role in the adoption of agricultural practices and also participated in educating others through mass meetings, group talks and individual contacts.

Deb and Agrawal (1974) stated that most of the leaders identified had functional importance in agriculture and welfare activities.

Subramaniam (1980) stated that key communicators (leaders) played a dominant role in disseminating improved farming practices through interpersonal communication. Singh (1987) opined that it is 
difficult for any country to provide enough number of extension workers to reach each and every family for its social welfare programmes. This problem can be solved to some extent through the use of local leaders. Local leaders who have adopted improved practices extend the same to others. The common man has much faith in the local leaders.

Sinha et al., (1988) stated that opinion leaders communicated with opinion seekers most frequently during the knowledge and persuasion stages.

Dasgupta (1989) was of the view that since Indian farmers rely predominantly on interpersonal sources of information within the village, opinion leaders have a very crucial role to play in bringing about a technological change in agriculture. Their relatively high socio-economic status, ability to take risk, willingness to try out new ideas and wider contact with institutional sources allow them to be among the first in a village to be aware of an innovation and adopt it. Since they are sought by other farmers for information and advice, they act as "middlemen" who are not only in contact with other members of the local system, but also mediate values and demands of modernisation and transmit modern culture and technology to people who are rooted in traditional values and beliefs.

Chaubey et al., (1999) stated that leadership may rightly be called the sheet-anchor of successful extension work. It is impossible to think of effective extension work without active involvement of village leaders in planning, executing and evaluating village extension programme.

Chitambar (2005) recorded that the type of political leadership and individuals in power influences the rate and direction of change.
The assessment of those who wield power in respect of the existing social situation, technological and non-technological changes and opportunities for such development and change is of considerably more significance than the assessment of those who do not have power in society. In some societies the political leadership controls the economy; significant influence is exercised by them in the direction and rate in which changes take place in society.

Posner (2006) noted that the leaders' primary contribution is in the recognition of good ideas, the support of these ideas and the willingness to challenge the system to get new products, processes, services and system adopted. It might be more accurate, than to say that leaders are early adopters of innovations.

Leaders know well that innovation and change all involve experimentation, risk and failure. They proceed anyway. One way of dealing with the potential risk and failures of experimentation is to approach change through incremental steps and small wins.

Northouse (2007) was of the opinion that in some situations the task characteristics also have a major impact on the way a leader's behaviour influences subordinates motivation. The task characteristics may call for leadership involvement. Tasks that are unclear and ambiguous call for leadership input that provides structure. Also tasks that are highly repetitive call for leadership that gives support in order to maintain subordinates motivation. In works settings where the formal authority system is weak, leadership becomes a tool that helps subordinates by making the rules and work requirements clear. In context where the group norms are weak or non supportive, leadership assists in building cohesiveness and role responsibility. Prasad (2007) 
reported that leadership is an important factor for making any type of organisation successful. Throughout the history it has been recognised that the difference between success and failure, whether in a war, a political movement, a business or team gain, can be attributed largely to leadership. The importance of good leadership is distinctly visible in motivating employees, creating confidence and building morale.

\section{References}

Adair, J. (2005) The action centred leader, Jaico Publishing House, Mumbai.

Bogardus, E.W. (1934) Leader and leadership, Appleton Century Company, New York.

Babu, G.R. (2008) Research methodology in social sciences, Concept Publishing Company, New Delhi.

Baldoni, J. (2006) How great leaders get results? Tata McGraw Hill Publishing Company Ltd., New Delhi.

Bareth, L.S. and Sarkar, J.D. (2003) Role of opinion leaders in rural development and community advancement, Manage Extension Research Review, 67-73.

Beal, G.M., Bohlen, M.M. and Raudabaugh, J.N. (1960) Leadership and dynamic group action, The Iowa State University, Ames, Iowa.

Blanchard, K. and Muchnick, M. (2004) The leadership pill, Pocket Books, New York.

Brunner, F. and Young, H.P. (1949) Rural America and extension service: Bureau of publication, Teachers college, Columbia University, New York.

Chakraborty, D. and Chakraborty, S.K. (2004) Leadership \& Motivation: Cultural Comparisons, Rupa \& Co., New Delhi.

Chalapathi, B.V. and Raghavulu, B.V. (2005)

Decline of good governance Decentralisation, Third Concept,
August, 2005: 39-41.

Chaubey, B.K., Rai, B.B. and Shrivastava, J.P. (1999) Extension Education, Aman Publishing House, Meerut (U.P.)

Chitambar, J.B. (2005) Introductory rural sociology, New age international (P) Ltd.. Publishers, New Delhi.

Dahama, O.P. and Bhatnagar, O.P. (2001) Education and communication for development, Oxford and IBH Publishing Co. Pvt. Ltd., New Delhi.

Dasgupta, S. (1989) Diffusion of agricultural innovations in village India, Wiley Eastern Ltd. New Delhi.

Dashora, K.B. (2008) Women empowerment and panchayati raj, Third Concept, December 2008: 54-58.

Deb, P.C. and Agrawal, B.K. (1974) Rural leadership in Green Revolution, Research Co. Publishers, Delhi.

Haiman, F.S. (1951) Group leadership and democratic action, Houghton Mifflin Company, Cambridge.

Hooja, R. (2008) Capacity building for Rajasthan's panchayat representatives and functionaries; What the training efforts should cover, Indian J. Public Adminstration, 54(1): 1-20.

Kaur, G. (2003) Political dynamics of panchayati raj in India, Third Concept, September 2003: 17-25.

Khalge, M.I., Chole, R.R. and Bhosale, R.R. (2010) Role performance of gram panchayat members, Agriculture Update, 5 (1\&2): 47-51.

Kuppuswamy, B. (1973) Elements of social psychology, Vikas Publishing House Ltd., New Delhi.

Lalneihzovi (2009) Decentralised governance for rural development in Mizoram: Problems and prospects, Indian J. Soc. Dev., 9(1):59-66.

Leagans, J.P. (1963) The communication process in rural development. Cornell University, Ithaca, New York.

Limbadri, R. (2007) Grass root democracy: 
The experience of Dalits in P.R.I.'s, Indian Journal of Public Administration, 53(4): 788-796.

Maxwell, J.C. (1999) The 21 irrefutable laws of leadership, Magna Publishing Co. Ltd., Mumbai.

Maxwell, J.C. (2001) Developing the leader within you, Magna Publishing Co. Ltd., Mumbai.

Mehta, S.R. (1972) Emerging pattern of rural leadership, Wiley Eastern Pvt. Ltd., New Delhi.

Mohanty, G. (2006) Social Psychology, Kalyani Publishers, Ludhiana (Punjab).

Pachouri, P. (2007) A study of role performance of women panchayat leaders in village development of Narsinghpur district of M.P., Unpublished M.Sc. (Ag) thesis, JNKVV, Jabalpur.

Prasad, L.M. (2007) Organisational behaviour, Sultan Chand \& Sons, Educational Publishers, New Delhi.

Mathur, S.S. (2007) Social Psychology, Vinod Pustak Mandir, Agra - 2 (U.P.)

Northouse, P.G. (2007) Leadership: Theory and Practice, Sage Publications, Los Angeles

Posner, K. (2006) Leadership the challenge, Willey India (P.) Ltd., New Delhi.

Radhakrishnan, M.G. (2010) Action heroes The citizens who can and do, India Today - special issue, July 26:94.

Raheja, P.C. (1956) Role of rural leadership in the development of intensive cultivation, Indian J. of Agronomy, 1: $127-131$.

Ray, G.L. (2001) Extension Communication and Management, Naya Prakash, Calcutta.

Robbins, S.P. (1997) Organisational behaviour: Concepts, Controversies and Applications, Prentice Hall of India Pvt. Ltd., New Delhi.

Sanderson, D. (1940) Leadership for rural life, Associated Press, New York.
Samad, M.A. (2007) Women empowerment and panchayati raj institutions in Kerala, Kurukshetra, March 2007:37-41.

Sharma, R. (2006) Leadership Wisdom, Jaico Publishing House, Mumbai.

Shrivastava M. (2010) Action heroes - The citizens who can and do, India Today special issue, July 26:96-97.

Shrivastava, K.K. (1999) Role perception and role performance of formal leaders working under panchayati raj system in Kheda district of Gujarat state, Unpublished Ph.D. Thesis, Gujarat Agricultural University, Anand Campus, Anand.

Shrivastava, P. (2003) Job performance of village panchayat leaders of Jabalpur block, district Jabalpur, M.P., Unpublished M.Sc. (Ag) thesis, JNKVV, Jabalpur.

Shrivastava, P. (2011) An analytical study on role performance of leaders in the three tier Panchayati Raj Institutions of Rajnandgaon district of Chhattisgarh., Unpublished Ph.D.(Ag) thesis, IGKV, Raipur.

Shrivastava P. and Shrivastava K.K.(2018) Multiple Regression Analysis of Characteristics of Panchayat Leaders and its Impact on their Role Performance. International Journal of Agriculture Sciences, ISSN:0975-3710 \& E-ISSN: 0975-9107, Volume 10, Issue 03,pp.-5145-5148.

Shrivastava P. and Shrivastava K.K.(2018) Path Analysis of Characteristics of Panchayat Leaders and its Impact on their Role Performance. Int.J.Curr.Microbiol.App.Sci. $\quad 7(2)$ : 1587-1595.

Shrivastava P., Shrivastava K.K., and Kumar Dilip (2018) Socio-Economic characteristics on performance of Panchayat Leaders of Chhattisgarh. Journal of Pharmacognosy and Phytochemistry, pp.-526-530. 
Shrivastava P. and Shrivastava K.K.(2018) Correlation Analysis of Performance of Panchayat Leaders in Rajnandgaon district of Chhattisgarh. International Journal of Agricultural Science and Research, ISSN:2250-0057 \& E-ISSN: 2321-0087, Volume 08, Issue 01,pp.145-152.

Shrivastava P. and Shrivastava K.K.(2018) Communicational Characteristics and Role Performance of Panchayat Leaders. Trends in Biosciences - An International Journal, ISSN:0974-8431 \& E-ISSN: 0976-2485, Volume 11, Issue 02,pp.176-184.

Shukla, S. (2009) A study on performance of entrepreneurial activities among the members of women self help groups (SHGs) in Dharamjaigarh block of Raigarh district (C.G.), Unpublished M.Sc. (Ag) thesis, IGKV, Raipur.

Singh, Y.P. (1973) Key communicators of Agricultureal innovations, Satish Book Enterprise, Agra.

Singh, R. (1987) A text book of Extension Education, Sahitya Kala Prakashan, Ludhiana.

Sinha, H.S.P., Khanal, J.P. and Prasad, N.
(1988) Communication behaviour of opinion leaders of Nepal, Journal of Rural Development, 7: 333-341.

Stogdill, R.M. (1979) Hand Book of leadership: A survey of theory and research, The Free Press, New York.

Subramanian, K.S. (1980) An analysis of interpersonal network in the diffusion of agricultural innovations, Unpublished M.Sc. (Ag) thesis, TNAU, Coimbatore.

Tennebaum, R. Weshler, I.R. and Massarik, D. (1961) Leadership and organisation: A Behavioural Science Approach, McGraw Hill Book Company, New York.

Vas, L.S.R. and Vas, A.S.R. (2007) Secrets of Leadership: the panchatantra way, Pustak Mahal, New Delhi

Vatsyayan, Dr. (2007) Rural sociology, Kedar Nath Ram Nath, Meerut (U.P.)

Verma, H. (2006) The Avatar way of leadership: leadership for the twenty first century from Rama, Krishna and Draupadi, Rupa \& Co., New Delhi.

Wilkening, E.A. (1952) Informal leaders and innovators in farm practices, Rural Sociology, 17: 272-275.

\section{How to cite this article:}

Shrivastava, P., K. K. Shrivastava and Anupama Verma. 2020. A Collection of Review on Concept of Leaders, Leadership and Importance of Leaders. Int.J.Curr.Microbiol.App.Sci. 9(03): 926-936. doi: https://doi.org/10.20546/ijcmas.2020.903.109 